\title{
Scripsi manu mea Hartmann Schedel in Munich, Bayerische Staatsbibliothek, clm 490
}

Keywords: German humanism, Hartmann Schedel, palaeography, codicology, book history

DOI: $10.4312 /$ ars.8.2.119-130

The Padua-trained ${ }^{1}$ medical doctor Hartmann Schedel $\left(1440-1514^{2}\right)$ of Nuremberg is today perhaps best known for his Liber Chronicarum, printed in Latin and German (Weltchronik) in 1493 with an ambitious programme of xylographies. ${ }^{3}$ Thanks to his well-spent study years in Padua (1463-1466), ${ }^{4}$ he also played an important role in the dissemination of Italian humanism north of the Alps, as witnessed, for example, by his collection of inscriptions ${ }^{5}$ and transcription of part of the first book of Poggio Bracciolini's De varietate fortunae contained in the ms. entitled Liber antiquitatum cum epitaphiis (Munich, Bayerische Staatsbibliothek, Clm

1 The research for this article was financed by the Academy of Finland and University of Jyväskylä project no. 267518 Transmission of Knowledge in the Late Middle Ages and the Renaissance (2013-2017). I have the pleasure of thanking the staff of the MSS reading room of the Bayerische Staatsbibliothek (= BSB), Munich, for excellent working conditions in March and July 2014. Thanks also to Stefania Fortuna (Ancona/Recanati), who provided important insights on Galenic texts and great fun in June 2014, and to Elizabeth Peterson (Helsinki), who kindly revised my English.

2 The classic account by Wattenbach (1871) is still largely valid for the wealth of information provided by transcriptions from manuscripts. For the most extensive analysis of Schedel's library, see Stauber (1908). Cf. also: Welten des Wissens, 2014.

3 Worstbrock $(2005,290)$ characterises it as the most important monument to printed graphics before Dürer. For an analysis of the production process, see Reske (2000). For the palaeography of the Weltchronik, see Koch (2010, 365-384). Thanks to Nataša Golob (University of Ljubljana) for drawing my attention to this article. For Schedel's own copy of the Latin text, Munich, BSB, Rar. 287, http://dfg-viewer.de/show/?set\%5Bmets\%5D=http\%3A\%2F\%2Fdaten.digitale-sammlungen. de\%2F\%7Edb\%2Fmets\%2Fbsb00034024_mets.xml.

4 Hartmann Schedel spent the years 1463 to 1466 at the university of Padua, and was taught by, among others, Matteo Boldiero, whose lectures were attended in the same period also by Conrad Schelling of Heidelberg (c. 1432-1514), who was to be Schedel's colleague as personal physician to Elector Palatine Philip, Duke of Bavaria (r. 1476-1508), see Merisalo (2006, 497, 502). Schedel's autograph Munich, BSB, clm 13, f. 17v has a portrait and an epitaph to Boldiero, and on f. 129v a colophon referring to him as preceptor mei amantissimus.

5 According to Worstbrock (2005b, 327 n. 54), Schedel's pre-existing interest in inscriptions was remarkably intensified from the beginning of his stay in Padua. This should not surprise, considering the general antiquarian interests and epigraphical studies of the circle of Giovanni Marcanova (d. 1467), with Andrea Mantegna and the scribe Felice Feliciano in the 1450s and 1460s, see e.g. Gionta (2007). 
716), ${ }^{6}$ the Latin speeches of Demetrius Chalcondylas, whose lectures he attended at Padua (Clm 28128, Illustrations: 1,2$),{ }^{7}$ and the Erotemata grammaticalia of Manuel Moschopoulos in Greek (Munich, BSB, cod. gr. 253). His rich library, ${ }^{8}$ consisting of manuscripts, both autographs and written by others, and printed books, was bought from his grandson, Melchior Schedel, by Hans Jakob Fugger of Augsburg (15311598 ) in 1552. Fugger's library was passed to the Bavarian Court Library in $1571 .^{9}$ This article details one of the autograph manuscripts, the $\mathrm{clm} 490$, containing medical texts, from the points of view of palaeography, codicology and cultural history.

\section{The organisation of Schedel's library}

Two extensive thematically arranged catalogues of the library have been preserved, in Schedel's autograph manuscript, BSB, clm 263, f. 126-160, after 1498 and c. $1507^{10}$ (entitled A by Ruf, who republished the list), and in the sixteenth-century copy of the Schedel family book, Berlin, SBB-PK, fol. 447, f. 255v-257'11 (entitled B by Ruf, who gave a full edition). ${ }^{12}$ In addition, two fragments, entitled $\mathrm{C}$ by Ruf, retrieved from BSB, $2^{\circ}$ Inc. c.a. 1487 (GW 09704) and D, secured from BSB, clm 319, ${ }^{13}$ provide some additional information on the library.

6 For a description of BSB, clm 716, see Merisalo (1993, cf. Bracciolini, p. 55-56); an analysis of the contents, see Worstbrock (2005b, 311-338).

7 For this autograph, see http://daten.digitale-sammlungen.de/ db/0008/bsb00083096/images/index.ht $\mathrm{ml}$ ?id=00083096\&fip=eayaxsxdsydeayaxsfsdreayaqrseaya,\%20eayayztssdasyztswwyztseayafsdren\&n o=4\&seite=6, 3 March 2014: f. 1v C Iste Grecus fuit Demetrius Atheniensis. Qui publice Padue / primo Erothimata deinde Hesiodum nobis exposuit.:-; f. 2 : C Oratio. Greci. viri clarissimi; .habita In principio sur lecture: Anno d(omi)ni .Mccclxiij; Padue.

8 On the library, see Stauber (1908); Worstbrock $(2005,290)$. Some of the books had belonged to Hartmann's cousin Hermann Schedel (1410-1485), M.D. Pad. and city doctor of Augsburg (see below), Stauber $(1908,12)$. One of these manuscripts is clm 207, mainly written by Hermann during his stay in Padua in the 1440s, completed and decorated by Hartmann.

9 Stauber (1908, 146); Schneider $(1984,409)$. The Schedel heirs had presumably, in breach with Hartmann's testamentary dispositions, sold some volumes even before 1552. In Stauber's estimation the Schedel volumes present at the Bavarian State Library in his time represented approximately the half of the original collection (Stauber, 1908, 147). For Hans Jakob Fugger's library, see Kellenbenz $(1980,89)$.

10 Edition in Stauber (1908, 103-145); for the dates, see Stauber $(1908,102)$. The catalogue in clm 263 is now accessible at http://daten.digitale-sammlungen.de/ db/0006/bsb00066373/images/index.html?fi $\mathrm{p}=193.174 .98 .30 \&$ seite $=275 \& \mathrm{pdf}$ seitex $=$.

11 Thanks to Eef Overgaauw (Staatsbibliothek zu Berlin, Preußischer Kulturbesitz) for facilitating the consultation of the Berlin ms. in April 2014. While the Berlin catalogue, covering the works present in the first part of the Munich catalogue, is divided in the same thematical sections as the Munich ms., the order of the works vary, and each catalogue contains works absent in the other one, as shown by Stauber 103, who presents an edition of the Munich catalogue, annotated with regard to the Berlin catalogue, on pp. 103-145.

12 Edition of the lists entitled A and B in Ruf (1939, 807-839). A further copy of the family book is in private ownership (thanks to Eef Overgaauw for the information).

13 For the fragments, see Ruf $(1939,806-807)$. 


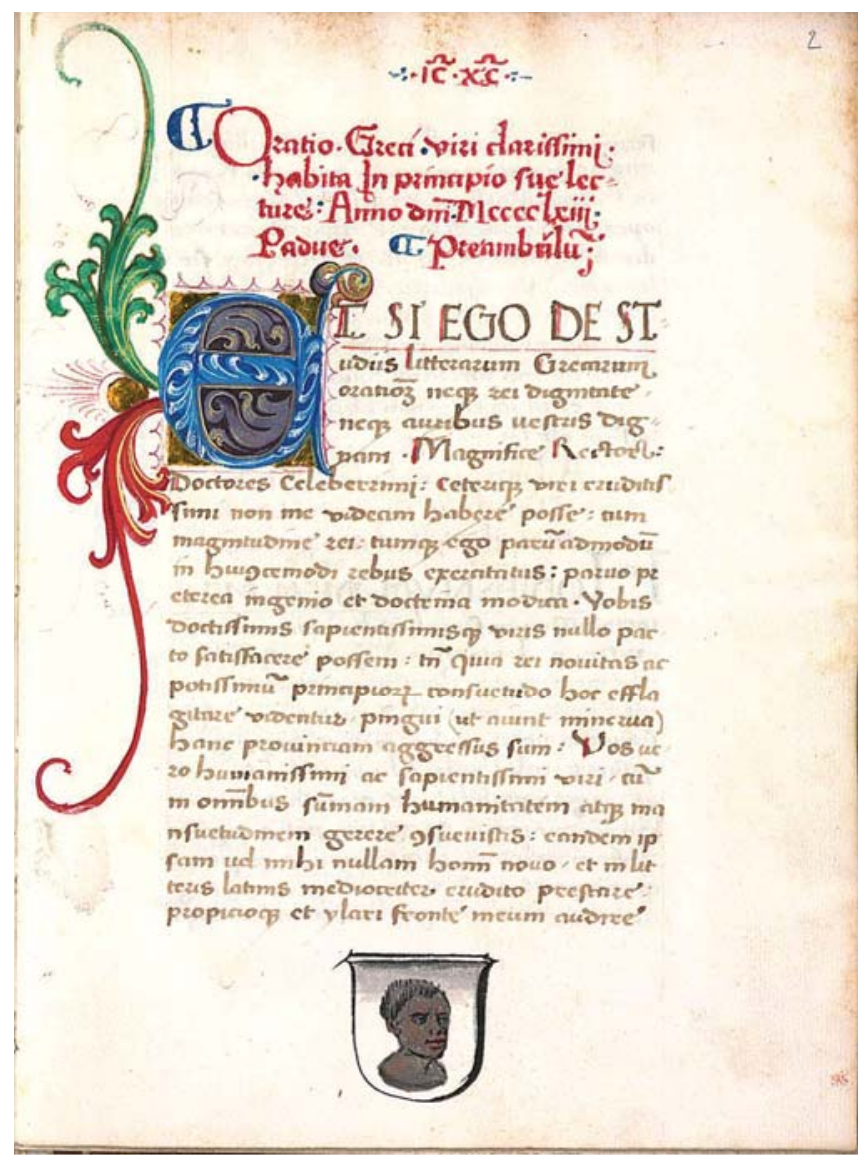

Illustration 1: Munich, Bayerische Staatsbibliothek, clm 28128, fol. 2r, Schedel's all'antica hand and arms; (C) BSB, Digitalisierungszentrum.

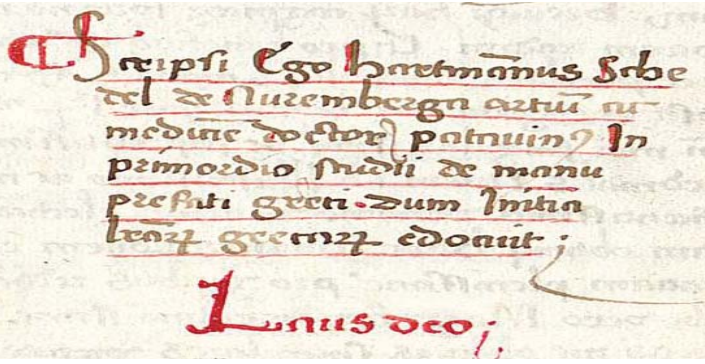

Illustration 2: Munich, Bayerische Staatsbibliothek, clm 28128, fol. 10v:

Schedel's colophon: Scripsi Ego hartma(n)nus Schedel de Nuremberga artiu(m) $\mathrm{cu}(\mathrm{m})$ medici(n)e doctor patauin(us) In primordio studii de manu prefati greci. dum Initia l(itte)rar(um) grecar(um) edocuit; Laus deo; () BSB, Digitalisierungszentrum. 
Schedel's library was studied by F. J. Worstbrock some twenty years ago. ${ }^{14}$ On examining the published book lists he came to the conclusion that the works are listed according to the hierarchy of university faculties in rising order, from artes through medicine and law to theology, with humanist studies (ars humanitatis) placed after artes. ${ }^{15}$

Most of the volumes bear Schedel's hand-written ex-libris, which takes slightly different forms, e.g. LIBER.DOCTORIS.HARTMANNI.SCHEDEL. DE NUeREMBERGA (Munich, BSB, cod. gr. 253, front pastedown). In clm 207 (see above n. 8), mainly written by Hermann Schedel but completed and refinished by Hartmann after the death of his cousin; the latter explains the rationale of the library:

clm 207, f. 3 modern: Int(er) quos [= students of Antonio Cermisono, Hermann's influential teacher at Padua] non infimo ingenio ac solercia excellit Solertissim(us) $\operatorname{artiu}(m)$ et medicine doctor Herman(us) SchedeL patruus meus Qui prescripta et sequencia consilia / partim ex ore suo / partim p(ost) suum obitum diligentissime collegit Et ista consilia p(er) manu(m) suam scripta / ex ordinacione sui testame(n)ti Aput me hartma(n)nu(m) Schedel doctorem patruu(m) suum et liberos sue familie p(er)manere disposuit Qua(m)obrem meliori ornatu ac decore cum prologo ac $p(r e) m i s s i s$ ornare decreui : ut sua accurata diligencia ceteris nocior Et ad salutem a $(n) i(m)$ e sue memoria vberior fieri possit.

The library was indeed meant to be a family heirloom, according to Hermann's testament. Hartmann contributes to the commemorative dimension by adding lustre to Hermann's manuscript, through which operation future readers will be able to appreciate even more the latter's accurata diligencia. The memoria uberior will also contribute to the salvation of Hermann's soul. The common project is clearly announced by the presence of both men's ex-libris on the front pastedown of the manuscript: Hermann's C Iste liber est m(agist)ri Hermanni Schedel de Nuremberga is accompanied by Hartmann's LIBER. DOCTORIS. HARTMANNI. SCHEDEL. DE NVoREMBERGA .:-

14 Worstbrock (2005).

15 Worstbrock $(2005,295)$. The author convincingly polemicizes against earlier interpretations (e.g. Milde, 1984, 19-31) according to which Schedel's order would reflect the triumph of humanist studies over theology. 


\section{Bayerische Staatsbibliothek, Clm 490}

\section{Description. ${ }^{16}$}

Paper, $21.0 \times 16.7$ (15.1 x 9.0), long lines, 0.7, Schedel's own foliotation 4-227 (f. 227 being the rear pastedown). Quires: I-4(-2) II-8+2 III-10+1 IV-X-10 XI-10-1 XII-8 XIII-XV-10 XVI-10+3 XVII-XXIII-10 XXIV-6-1. On f. 8, top margin :.IC. XC. (=Iesous Christos), typical of Hartmann's autographs. Gold-enhanced initial, floral letter and marginal decoration; Schedel's arms in the lower margin, with floral decoration.

\section{Contents}

\section{f. 4-5 I*NDEX.EORVM.QVE.IN.ISTO.LIBRO CO(N)TINE(N)T(VR). OPERA.} GALIENI.*; first codicological unit (1488): ${ }^{17}$ f. 7v De Galieno medico (short biography of Galen); ${ }^{18}$ f. 8-16v Galen, De introductione medicorum; f. 17-19v Galen, De substantia uirtutum naturalium (tr. Niccolò da Reggio); second codicological unit (1488): ${ }^{19}$ f. 20-21 Ps. Galen, De virtutibus dispensantibus corpus nostrum; f. 21v-25v Galen, De optima constructione corporis (tr. Niccolò da Reggio); f. 26-27v Galen, De bono habitu corporis (tr. Niccolò da Reggio); f. 28-30 Galen, De simulantibus; f. 30v-50v Galen, De virtutibus cibariorum (tr. Attralfo da Pistoia, Bologna 1300); f. 51-54v, Ps. Galen, De cura yctericie; f. 55-69, Ps. Galen, De marasmo (tr. Niccolò da Reggio); f. 69v-78, Galen, De virtute consuetudinis (tr. Niccolò da Reggio); third codicological unit (1490): ${ }^{20}$ f. 78v-83 Galen, De exercitio parue spere; f. 83v-92v Galen, De inaequali discrasia (tr. Niccolò da Reggio); f. 93-101v Ps. Galen, Liber farmacorum; f. 102-128 Galen, De sectis (with the prologue and commentary until 9.35 by John of Alexandria); fourth codicological unit (1490): ${ }^{21}$ f. 129-133 Galen, De compendiositate pulsus (tr. Burgundio of Pisa); fifth codicological unit (1503)::22 f. 134-155v Ps. Galen, De spermate, ${ }^{23}$ sixth codicological unit (1490): $:^{24}$

16 A summary description in Halm, von Laubmann, Meyer (1892, 138, ad 490). In the following, the asterisk marks the beginning and the end of the use of red ink.

17 F. 19v: C 1488 . :.H;S. C *Perscripsi hos libros Galieni et aliquos sequentes ego hartma(n)nus Schedel artium et medici(n)e doctor In Rure fundi Rentze(n)hoff. Tempore autumpnali du(m) aucupio operam dedi. :-

18 Contrary to the lives of Averroes and Gentile da Foligno (see below notes 28 and 31), the text differs considerably from that in the Liber Chronicarum (copies consulted: Munich, BSB, Rar. 287, GW M40784, Nurembergae 1493, f. 113; 2 Inc. c.a. 3536 n., GW M40786, Augustae 1497, f. 125va-b).

19 F. 78: H.S. 1488. C LAVS DEO.

20 F. 128: 1490 :-

21 F. 133: C DEO LAVS. 1490. H.S. ‘.,

22 F. $155 \mathrm{v}:{ }^{*} \mathrm{C}^{\star}$ LAVS DEO. C.H.SD. - : 1503. :-

23 Galba + Berlin 1-34, see Merisalo (2013, 934).

24 F. 163: C C .LAVS DEO.:- .H.S.:-.1490.,.., 
f. 156-163 Galen, De heresibus modernorum medicorum; seventh codicological unit (1489):: ${ }^{25}$ f. 165v De vita et operibus Auerrois; ${ }^{26}$ f. $166-184 \mathrm{v}$ Averroes, De theriaca; seventh codicological unit (1488): ${ }^{27}$ f. 195v Life of Gentile da Foligno of Perugia; ${ }^{28}$ f. 196-205 Sermo ad Reco(m)mendac(i)o(ne)(m) artium et medicine pro pri(n)cipio studij; f. 205v210 Sermo pro quodam doctorando (compiler, place and date, f. 210: Paulus, Padua 16 March 1386); eighth codicological unit (1488): ${ }^{29}$ f. $215-218 \mathrm{v}$ sermon beginning IOHANNES.LABORAVIT (compiler, place and date, f. 218v : Paulus, Padua 10 August $1385)$; ninth codicological unit (1488): ${ }^{30}$ a fragmentary sermon on Avicenna, Canon, fen 1, chap. on anatomy of muscles; two other sermons by Gentile da Foligno (d. 1348). ${ }^{31}$

\section{Scripsi ego Hartmannus Schedel}

The manuscript begins with a list of contents covering the Galenic section on ff. 4-5. The layout and colouring are identical to those encountered, for example, in

25 F. 184v .Laus deo; C Scripsi hartma(n)nus Schedel medicine doctor. Anno do(min)I Mcccclxxxix. Nure(m)berge.

26 The text is largely identical to that of the Liber chronicarum (LC), ed. 1493 f. 202 (= LC93) and ed. 1497 (= LC97) f. 225va (the variants of the latter in brackets). Clm $490 \mathrm{f}$. 165v: AVerrois [q(u)oq(ue) add. $L C$ ] medicus cognomento $\mathrm{Co}(\mathrm{m})$ mentator : philosophus quidem [et ip(s)e add. $L C$ ] clarissimus [vacat $L C$ ]: apud Corduba $(\mathrm{m})$ hispanie [hyspanie LC97] vrbem hoc tempore sc(ilicet) 1150 [sc. 1150 vacat $L C$ ] (ut ex libro eius qui de celo tractat habetur) floruit. [Fuit enim) a nati(ui)tate (christ)i an(no) M.cl vt asserit (con)ciliator. et egidi(us) ro(manus) in suis q(u)otlib(et) [q(u)otlibetis LC93]. q. de vnitate i(n)tellect(us). dicit se vidisse filios auerrois in curia frid(erici) imp(er)a(toris) add. $L C$ ] Et multa [E. m. > Multa aute $(\mathrm{m})$ LC] composuit : Et adeo excellent(er) in o(mn)es Aristotelis [arestotil(is) LC] libros scripsit ; ut $\mathrm{Co}(\mathrm{m})$ menta $<\mathrm{to}>\mathrm{r}($ is $)[\mathrm{co}(\mathrm{m})$ mentatoris $\mathrm{LC}]$ cognomentum promeruerit : Dein(de) de substancia orbis. [de tiriaca $L C$ ] et de Sectis composuit.[e.d.s.c. vacat $L C$ ] Librumq(ue) [libr(um) q(u)o(que) LC] pulcrum [pulchr(um) LC97] de medicina collegit [colliget appellatu(m) LC]. Atq(ue) de Tyriaca: et de *:- ${ }^{*}$ diluuys [Atq(ue) --- diluuys vacat $L C$ ] ac alia multa [alia add. LC97] edidit. Auicenne eni(m) medici[e.m. > t(ame)n ac medicor(um) LC] emulus et inimicissimus [et i. > dictus $L C$ ] fuit. Consequently, here, as in the other lives, Hartmann elaborated on the shorter text for the Liber chronicarum.

27 F. 210: H.S. 1488.

28 Again, a text largely identical to that of the LC93 f. 224 and $L C 97$ f. 252 (same conventions as above): GENTILIS.DE FVLGINEO.PERVSIN(VS)[G.D.F.P. > Gentilis medic(us). LC] C Gentilis fulginas [perusin(us) add. LC] prestabilis sapiencie medic(us) hoc ipso t(em)p(or)e s(cilicet) M CCC XIX. precedenciu(m) medicor(um) [s(cilicet) --- medicor(um) $>$ diui p(re)teriti medici $L C]$ non inferioris ingeny [ingenij $L C$ ] aut fame fuit : $\mathrm{Q}$ (uod) potissimum e(ius) accuratissimi co(m)mentarij In quinq(ue) [vacat $L C$ ] Auicenne libris testimonium perhibent. [fuit eni(m) subtilissim(us) rimator verbor(um) auice $(\mathrm{n})$ ne. add $L C]$ Hic etia $(\mathrm{m}) \mathrm{p}($ re)ter predictos co(m)mentarios [(con)silia varia etia $(\mathrm{m})$ add. $L C]$ Con(tra) pestem [libr(um) vacat $L C$ ] composuit Ac questio(ne)(m) [questiones $\mathrm{p}($ re)cipue $L C$ ] de gradib(us) medicinar(um) [ac alias add. $L C$ ] subtilissima(m) [subtilissimas $L C$ ] disputauit.

29 f. $218 \mathrm{v}:{ }^{*}$.H.X. 1488. :-*

30 F. 223v: C Finiunt Sermones generales subtilissi(mi) doctoris. Gen $<$ til $>$ is de fulgineo pro pri(n)cipio studij et pro doctorand(is) ac inicys libror(um) . (et) p(er) paulu(m) riet(erium[?]) collecte C Scripsi ego hartma(n)nus Schedel artiu(m) (et) me(dici)ne doctor. Anno d(omi)ni .1488.o In-Nure(m)(berg)a.

31 F. 223v: C Scripsi ego hartma(n)nus Schedel artiu(m) (et) me(dici)ne doctor. Anno d(omi)ni .1488. o In-Nure(m)(berg)a. 
Hartmann's copy of a Galen, which was printed in Venice by Johannes Petri Pincius on 27 August 1490 (Hain ${ }^{\star} 7427$, GW 10481), and numerous manuscripts of the 1480s, 1490 s and 1500s.

Following the collection of Galenic (and pseudo-Galenic) texts, which are mostly works studied by advanced students of medicine since the thirteenth century, are texts by other important medical authorities, Averroes and Gentile da Foligno (d. 1348). Most of the copies are, according to Hartmann's autograph notes, from 1488 and 1490, with the exception of the fifth codicological unit, which dates from 1503. The three textual sections also contain short biographies, most probably written by Hartmann himself, since apart from the life of Galen, they are repeated almost word for word, with some additions, in the Liber chronicarum published in 1493 (see notes 3, 17 and 26 above). The Gentile section most probably derives from a Paduan manuscript written by a Paulus in 1386 (see above). ${ }^{32}$ With these texts bound together, Hartmann acquired a handy volume of central medical texts for his library.

The collection of works by and attributed to Galen in this manuscript is striking, due to the number of Latin translations by Niccolò da Reggio (fl. c. 1308-1345), copies of which are relatively rare (Nutton, 2011, pp. 481-491). Thus, the Galenic treatise De substantia virtutum naturalium, which consists of the two final chapters of De placitis propriis $^{33}$ (Galen, 1999), is only preserved in five other manuscripts, with which Schedel's copy presents but few similarities. ${ }^{34}$

Schedel systematically inserted dates and places of copy in his autograph manuscripts. This is also the case with $\operatorname{clm} 490$, where all units are dated and signed by Schedel. On f. 19v he states:

C Explicit Liber Galieni de substancia virtutum naturalium// 1488//H.S.//Perscripsi hos libros Galieni et aliquos sequentes ego hartma(n)nus Schedel artium et medici(n)e doctor In Rure fundi Rentze(n)hoff. Tempore autumpnali du(m) aucupio operam dedi. ${ }^{35}$

In early autographs, such as clm 245 (explicit date: 1459), the hand writing the text on f. 154va, 190-223b, 224a-225v and 298v, 304a-305va, and present in numerous marginal annotations, leaves of additional texts, diagrammes, etc., is an upright, very small-format, experienced Gothic cursive. It is most probably Hartmann's early, preItaly hand.

32 Whether this Paulus is identical with the Paulus Riet(erius?) who, according to the colophon on $\mathrm{f}$. $223 \mathrm{v}$ (see n. 30) had "collected" the sermons, is unclear at present.

33 Clm 490 is Nutton's Nic., Galen $(1999,34)$.

34 Galen $(1999,35)$ : the set of texts is not reduplicated in any other manuscript; the source manuscript is presumably lost.

35 See Merisalo (2012, 103 and n.). 
Hartmann's hand in clm 490 may be characterised as a Gothic cursive-based all'antica book script. This type of script would seem to first appear in his manuscripts during his stay in Padua. The all'antica hand remains very stable until the end of his life. The most notable characteristics are the following: 1) the majuscule $a$ has the form of the Greek alpha; 2) the minuscule $a$ is cursive, frequently open below; 3) the long $s$ stays on the baseline, except for the ligature $s t$, where it descends below the line; 4) $f$ either stays on the baseline or descends very slightly; 5) final $s$ is round; 6) according to fifteenth-century Gothic cursive usage, $r$ is normally round even after $a, e, i, u$, but may be straight even after an $o ;{ }^{36} 6$ ) no diphthongs $a e$, oe nor $e$ caudata; 7) use of Uncial $d ; 8)$ a very round curve in $\mathrm{h}$, which stays on the baseline. The general appearance of the script is rounded. Initials are typically Gothic (Uncial) majuscules in red and blue with arabesques for larger sections, with simple initials for lower-hierarchy sections. Majuscules are regularly enhanced with red strokes.

As to codicology, Hartmann rules the page in dry point. The ink is most often light to medium light, greyish brown, though dark brown is used for example in clm 490, f. $134-155 \mathrm{v}$.

No specific display script is systematically used for titles in clm 490. On f. 102, 129, $134,156,166,196,211,215,220,222 \mathrm{v}$; however, capitalis is used for the first line of the text. This script has high $R$ and $M$ with middle juncture suspended at half-height of the vertical strokes, a slightly right-leaning $A$, serifs in some letters ( $I$, vertical stroke of $R, V, M)$.

\section{Conclusion}

It is not an exaggeration to state that Italy changed Hartmann Schedel's life. Following his cousin Hermann's advice, he left for Padua in 1463, where he stayed until 1466, gaining, like so many of his compatriots, the degree of doctor artium et medicine, acquainting himself not only with the latest developments of medicine under such famous masters as Matteo Boldiero but also with Italian humanism, Ancient Greek and epigraphy, which were to remain a life-long interest. During his years in Northern Italy, he seems to have abandoned his very professional Gothic cursive for an easily legible all'antica type of upright script, very different from the Italian antiqua and, for that matter, from the italics that were being developed in the 1450s and 1460s in Northern Italy. This characteristic script was to remain relatively unchanged for the rest of his life. Hartmann inherited the books of his cousin and continued to enrich the library not only by his own autographs and acquired hand-written and printed books but also through upgrading volumes through decoration, including miniatures, 
and especially systematic numbering of leaves, insertion of ex-libris notes and indices. Hartmann's volumes are thus immediately recognisable through his material presence. Hartmann's catalogues provide a detailed guide to the organisation of the library that purported to be a valuable family heirloom to pass from generation to generation. Even though Hartmann's heirs did not share his vision, the collection did not suffer significant dispersion before it was sold to the great bibliophile Hans Jakob Fugger, who, in turn, bequeathed it to the Dukes of Bavaria in 1571. The autograph clm 490 is a characteristic example of Hartmann's modus operandi, graphical culture and professional interests, an eloquent witness of the penetration of Italian humanism and academic culture as disseminated by one of the numerous Transalpine alumni of the international crossroads constituted by the University of Padua in the Late Middle Ages and the Renaissance.

\section{Bibliography}

\section{Sources}

Galeni opuscula, München, Bayerische Staatsbibliothek, clm 490.

$\mathrm{GW}=$ Gesamtkatalog der Wiegendrucke, herausgegeben von der Kommission für den Gesamtkatalog der Wiegendrucke, Bd. 1-7: Leipzig 1925-1938, Bd. 8-13: Stuttgart 1978-2013.

Hain, L., Repertorium bibliographicum, in quo libri omnes ab arte typographica inventa usque ad annum MD. typis expressi ordine alphabetico vel simpliciter enumerantur vel adcuratius recensentur, 1-5, Stuttgartiae 1856-1912.

Halm, C., von Laubmann, G., Meyer, W., Catalogus codicum latinorum Bibliothecae Regiae Monacensis 1.1. Codices num. 1-2329 complectens, ${ }^{2}$ Monachii 1892.

\section{Literature}

Bracciolini, P., De varietate fortunae. Edizione critica con introduzione e commento (ed. Merisalo, O.), Helsinki 1993.

Galen, On my own opinions (ed., tr. and comm. Nutton, V.), Berlin 1999.

Gionta, D., Marcanova (da/de Mercatonovo), G., Dizionario biografico degli italiani 69, 2007, http://www.treccani.it/enciclopedia/giovanni-marcanova_(DizionarioBiografico)/, 27 July 2014.

Kellenbenz, H., Hans Jakob Fugger, Weissenhorn 1980.

Koch, W., Epigraphisches zur Schedelschen Weltchronik, Die Leidenschaft des Sammelns. Streifzüge durch die Sammlung Woldan (hg. Holzer, G., Horst, T., Svatek, P.), Wien 2010, p. 365-384. 
Merisalo, O., Regionalism and Interregionalism in the Production of Mss.: the case of BAV, Vat. Pal. Lat. 1298, Miscellanea Bibliothecae Apostolicae Vaticanae 13, 2006, p. $493-517$.

Merisalo, O., La trasmissione del De spermate pseudo-galenico, Medicina nei Secoli 25 (3), 2013, p. 927-940.

Merisalo, O., The early tradition of the pseudo-Galenic De spermate (twelfth-thirteenth centuries), Scripta 5, 2012, p. 43-53.

Milde, W., Über Bücherverzeichnisse der Humanistenzeit (Petrarca, Tommaso Parentucelli, Hartmann Schedel), Bücherkataloge als buchgeschichtliche Quellen in der frühen Neuzeit, Wiesbaden 1984, p. 19-31.

Nutton, V., Pseudonymity and the critic: authenticating the Medieval Galen', Between text and patient: the medical enterprise in Medieval \& Early Modern Europe (ed. Glaze, F., Nance, B. K.), Firenze 2011, p. 481-491.

Reske, C., Die Produktion der Schedelschen Weltchronik in Nürnberg. The Production of Schedel's Nuremberg Chronicle, Wiesbaden 2000.

Ruf, P., Bistum Bamberg, München 1939.

Schneider, K., Die deutschen Handschriften der Bayerischen Staatsbibliothek München, Cgm 691-867, ${ }^{2}$ Wiesbaden 1984.

Stauber, S., Die Schedelsche Bibliothek, Freiburg i.B. - Berlin - Karlsruhe - München Strassburg - Wien - St Louis, Mo. 1908.

Wattenbach, W., Hartmann Schedel als Humanist, Forschungen zur deutschen Geschichte 11, 1871, p. 351-374.

Welten des Wissens: Die Bibliothek und die Weltchronik des Nürnberger Arztes Hartmann Schedel (1440-1514) (ed. Bayerische Staatsbibliothek), München 2014.

Worstbrock, F. J., Hartmann Schedels 'Index librorum' Wissenschaftssystem und Humanismus um 1500, Franz Josef Worstbrock, Ausgewählte Schriften 2 (hg. Köbele, S., Krass, A.), Stuttgart 2005, p. 290-310.

Worstbrock, F. J., Hartmann Schedels 'Liber Antiquitatum cum epitaphiis et epigrammatibus' Zur Begründung und Erschliessung des historischen Gedächtnisses im deutschen Humanismus', Franz Josef Worstbrock, Ausgewählte Schriften 2 (hg. Köbele, S., Krass, A.), Stuttgart 2005, p. 311-338. 


\section{Outi Merisalo \\ Scripsi manu mea Hartmann Schedel in Munich, Bayerische Staatsbibliothek, clm 490}

Keywords: German humanism, Hartmann Schedel, palaeography, codicology, book history

The Padua-trained medical doctor Hartmann Schedel (1440-1514) of Nuremberg is today perhaps best known for his Liber Chronicarum, printed in Latin and German (Weltchronik) in 1493 with an ambitious programme of xylographies. Thanks to his well-spent study years in Padua (1463-1466), he also played an important role in the dissemination of Italian humanism north of the Alps, as witnessed, for example, by his important collection of inscriptions and Humanist texts. His rich library, consisting of manuscripts, both autographs and written by others, and printed books, was bought from his family by H. J. Fugger of Augsburg (1531-1598) in 1552. Fugger's library was passed to the Bavarian Court Library in 1571 and is now housed at the Bayerische Staatsbibliothek in Munich. This article details one of the autograph manuscripts, the clm 490, containing medical texts. It gives direct access to Hartmann at work on his library, carefully writing out the contents in his allantica hand, numbering the folios, providing a list of contents, presenting authors in short biographies and, last but not least, scrupulously dating and often localizing the sections copied. 


\section{Outi Merisalo \\ Scripsi manu mea Hartmann Schedel v Münchnu, Bavarska državna knjižnica, clm 490}

Ključne besede: nemški humanizem, Hartmann Schedel, paleografija, kodikologija, zgodovina knjige

Nürnberški zdravnik Hartmann Schedel (1440-1514) je medicino študiral v Padovi, a je danes nemara najbolj znan po delu Liber Cronicarum (Weltchronik), natisnjenem leta $1493 \mathrm{v}$ latinskem in nemškem jeziku ter opremljenem z bogatim programom lesoreznih ilustracij. Ker je dobro izkoristil študijska leta v Padovi (14631466), je imel precejšnjo vlogo v širjenju italijanskega humanizma severno od Alp, kar med drugim dokazujejo humanistična besedila in obsežna epigrafska zbirka. Njegovo veliko knjižnico, v kateri so bili rokopisi, tudi avtografi, in tiskane knjige, je od njegove družine leta 1552 odkupil H. J. Fugger iz Augsburga (1531-1598). Leta 1571 je Fuggerjeva knjižnica postala del Bavarske dvorne knjižnice in je sedaj vključena v Bavarsko državno knjižnico v Münchnu. Prispevek natančneje obravnava enega od njegovih avtografov, sedaj clm 490, z medicinskimi besedili. Rokopis neposredno osvetljuje Hartmannovo urejanje lastne knjižnice, skrbno prepisovanje vsebin v pisavi all’antica, številčenje folijev, sestavljanje kazala, predstavljanje avtorjev s kratkimi življenjepisi ter navsezadnje tudi natančno zapisovanje datumov in včasih celo opredeljevanje prepisanih odlomkov. 